\title{
Fair and balance rate for benefits not scheduled in defined contribution plans*
}

\author{
Igor Ferreira do Nascimento ${ }^{1}$ \\ (iD https://orcid.org/0000-0003-1084-7849 \\ Email: igor.nascimento@ifpi.edu.br \\ Pedro H. M. Albuquerque ${ }^{2}$ \\ (D) https://orcid.org/0000-0002-1415-716X \\ Email: pedroa@unb.br \\ ${ }^{1}$ Instituto Federal do Piauí, Departamento de Formação de Professores, Teresina, PI, Brazil \\ ${ }^{2}$ Universidade de Brasília, Faculdade de Administração, Contabilidade, Economia e Gestão de Políticas Públicas, Departamento de \\ Administração, Brasília, DF, Brazil
}

Received on 06.24.2020 - Desk acceptance on 08.13.2020 - $5^{\text {th }}$ version approved on 02.11.2021

Associate Editor: Luís Eduardo Afonso

\begin{abstract}
The objective of this study is to propose a methodology that, using multiple decreases, in addition to classified by actuarial profile and source of social security costs, calculates actuarially fair and balanced rates for unscheduled collective costing benefits from Defined Contribution (DC) pension plans. There are no studies in Brazil about costing rates for benefits not scheduled in pension plans of the DC modality. Any institution that pays collective cost social security benefits must determine an actuarial rate that is not insufficient, generating a financial imbalance in the fund, nor excessive, compromising the participant's income. This work is the first study on costing rates for collective costing benefits from pension plans with DC modalities. Actuarially fair rates are obtained considering multiple decreases and equalizing the present value of contributions and the present value of pension and disability benefits, classified by actuarial profile and source of social security cost. The specific balance rate is determined for each source of social security costs and is obtained considering the actuarially fair rates for each actuarial profile. The general balance rate is obtained by the marginal contribution of each specific balance rate. The proposed methodology was used to calculate the rates of unscheduled benefits with collective costing in DC modality plans. The proposed methodology estimated that the legal changes, resulting from Constitutional Amendment 103/2019, indirectly increased by more than $4 \%$ the general balance rate of the unscheduled benefits of the Supplementary Social Security Foundation of the Federal Public Servant of the Executive Branch of the Federal Government (FUNPRESP-Exe).
\end{abstract}

Keywords: pension fund, risk mutualization, balance rates, fair rates, pension reform. 


\section{INTRODUCTION}

Closed Supplementary Pension Entities (Entidades Fechadas de Previdência Complementar - EFPC) are non-profit pension funds linked to the Complementary Pension Regime (RPC). They manage financial resources intending to guarantee to investors/participants, who are employees of a singular (single company) or plural (multi-sponsored) sponsor, a social security income or annuity to be received after the period of work activity or in case of loss of this condition.

These funds may offer benefit plans in the form of Defined Benefit (DB), Defined Contribution (DC), and Variable Contribution (VC). The modality is determined based on how the amount of the scheduled benefit (normal retirement) is calculated (Conselho de Gestão da Previdência Complementar, 2005). DB modality offers the participant a previously established scheduled benefit amount paid collectively by all participants. In the DC modality, the amount of the scheduled benefit is calculated based on the amount accumulated in the participant's exclusive account balance, i.e., each participant is responsible for financing his pension. Such a pension plan can then be considered a type of investment in which the capital invested by the participant is monetized to guarantee future social security benefits. On the other hand, the VC modality presents, simultaneously, characteristics of the DB and DC modalities. For example, in the contributory phase, the balance is accumulated individually to define the benefit amount. However, the costing is done collectively in the receiving period, the risk being shared among the fund's participants (Kolling, Petri, \& Marques, 2012).

Despite the specificities of the plan's regulations, most EFPCs, including Previ (Banco do Brasil Employees' Pension Fund), Petros (Petrobras Social Security Foundation), and Funcef (Federal Economists Foundation), offer plans from VC modality. In turn, Funpresp-Exe (Supplementary Social Security Foundation of the Federal Public Servant of the Executive Branch of the Federal Government) offers DC plans.

It is essential to highlight that the modalities of these plans are determined through the scheduled benefit. However, disability retirement benefits and (unscheduled) pensions may have different forms of cost, as can be seen in Funpresp-Exe (Law n. 12,618, 2012). Therefore, in this work, we will extend DB, VC, and DC definitions to also characterize how the benefit is funded and not just the plan modality. With this, we can say, for example, that in the General Social Security Regime (RGPS) and in the Regime of Social Security for Public Servants (RPPS), in which all benefits are collectively funded, both scheduled and unscheduled benefits are DB. In turn, in the RPC, considering the funds presented, there are plans with the scheduled DC or VC benefits and unscheduled DB and VC benefits.

One of the main challenges in the actuarial sector of such entities is to determine the actuarial rate, which is levied on the participants' income, necessary to honor social security commitments for the payment of normal retirement (Afonso \& Lima, 2011; Heiland \& Yin, 2014; Souza, 2018), disability retirement and dependents' pensions (Belloni \& Maccheroni, 2013; Corrêa, 2018; Gouveia, Souza, \& Rêgo, 2018). The concept of actuarial justice (Queisser \& Whitehouse, 2006) supports investigating how such rates are affected by changes in the plan's modality (Alonso-García, Boado-Penas, \& Devolder, 2018; Rodrigues \& Afonso, 2015), alteration of retirement rules (Martins \& Campani, 2019), and increased longevity (Gouveia et al., 2018) applied to general social security (Freire \& Afonso, 2015), private pension of public workers (Rangel \& Saboia, 2013; Rodrigues \& Afonso, 2015), and the RPPS (Corrêa, 2018).

When the benefit is paid collectively, the actuarial risk is shared through a single social security rate, allowing participants with less exposure to actuarial risks to pay relatively more than the participants with the highest risk (Donnelly, 2015). It is a known fact that women have a longer life expectancy than men. Some careers are also entitled to retirement at an earlier age and contribution time. Hence actuarial profiles must be determined to separate the different risks and social security costs. Thus, this work considers the entry age, sex, and occupation.

Therefore, from the expansion of DC, DB, and VC concepts for the unscheduled benefits, this work proposes a methodology to calculate the collective effort necessary to pay for the unscheduled benefits with DB and VC characteristics considering a pension plan with DC-type scheduled benefit. The classification by actuarial profile allows a detailed analysis of social security costs, representing the theoretical contribution of this work. Concerning the practical contributions, the proposed methodology was applied at FunprespExe, thus identifying that Constitutional Amendment (EC) n. 103/2019 indirectly increased the balance rate by more than $4 \%$. 


\section{RELATED WORKS}

The heterogeneity of the participants' life expectancy and their demographic distribution in pension plans imply different pension costs, measured using fair rates (Queisser \& Whitehouse, 2006) or actuarial balance (Gouveia et al., 2018). This allows identifying that, for example, participants with a longer life expectancy tend to be financed by participants with a lower expectation (Ayuso, Bravo, \& Holzmann, 2016; Souza, 2018).

Thus, the literature determines the actuarially fair rate equalizing the present value of contributions (VPC) and the present value of benefits (VPB) in three approaches. First, the risks of death and disability are ignored (Giambiagi \& Afonso, 2009). In this case, the rates are overestimated since, in reality, the payment of contributions and the receipt of benefits are conditional on the survival of the participant and/or beneficiary. The second considers only the probability of death (Afonso et al., 2011; Rodrigues \& Afonso, 2015; Souza, 2018). The third approach is found in studies that consider the risks of disability and death, which allows determining other retirement benefits originated by disability (Gouveia et al., 2018; Martins \& Campani, 2019). Gouveia et al. (2018) determine the contribution rates for normal retirement, normal retirement pension, disability retirement, and disability retirement pension for RGPS workers who earn one minimum wage. In turn, Martins and Campani (2019) analyze the impacts of the Proposed Amendment to Constitution 287/2016 on the wealth of RGPS participants, with no actuarial rates being calculated. Corrêa's work (2018) analyzes the actuarial rates necessary to fund the benefits of the Defined Benefit modality for entry age. From the perspective of RPC participants, contribution rates were studied to assess the impact on income during retirement for benefits with a DC characteristic (Rangel \& Saboia, 2013; Rodrigues \& Afonso, 2015; Souza, 2018) and to assess the impact on migration of the scheduled benefit from DC to VC (Kolling et al., 2012). However, all of these works aim to calculate benefit rates with $\mathrm{DB}, \mathrm{DC}$, or
VC characteristics. In other words, they do not consider pension plans whose scheduled and unscheduled benefits have different characteristics, which can be found in the plans pension fund in Brazil.

Internationally, studies on the calculation of fair rates for social security benefits assess the impact of the transition from $\mathrm{DB}$ to $\mathrm{DC}$ on normal retirement (Alonso-García et al., 2018), the effect of increasing longevity on fair contribution rates (Meneu, Devesa, Devesa, Domínguez, \& Encinas, 2016; Yang \& Huang, 2009), and the evolution between generations of workers (Heiland \& Yin, 2014). Considering the rates for normal retirement and disability pensions separately, Belloni and Maccheroni (2013) analyze the effects of increased longevity in the Italian pension system for DB benefits.

Thus, from the expansion of the DC, DB, and VC concept for unscheduled benefits, this work contributes to the literature by: (1) proposing a methodology for calculating actuarially fair and balanced rates in pension plans that have scheduled DC benefits, unscheduled DB and VC benefits (value of the benefit depends on the value of the scheduled DC benefit); (2) calculate the specific balance rate for each source of social security costs of the unscheduled DB and VC benefits through the actuarially fair rates classified by the actuarial profile; (3) calculate the general balance rate for the unscheduled DB and VC benefits using the balance rates specific to each source of social security costs; and (4) use the proposed methodology to calculate the impacts of demographic, actuarial, and legal changes (Constitutional Amendment n. 103/19) on the Funpresp-Exe unscheduled DB and VC rates, as well as suggesting changes to the regulations that minimize the actuarial imbalance caused indirectly by the change in legislation.

The following section presents the proposed methodology for calculating the actuarially fair rates per actuarial profile and the balance rates, considering unscheduled benefits $\mathrm{DB}$ and $\mathrm{VC}$ in pension plans where the scheduled benefit is DC. 


\section{METHODOLOGY}

Consider a pension plan in which the scheduled normal retirement benefit (AN) has a value defined by the individual mathematical reserve and paid individually (DC). Also, there are unscheduled pension benefits due to death and disability retirement up to $\mathrm{AN}$, with $\mathrm{DB}$ characteristics and value calculated per the salary. After the AN, there are pension benefits for death with an amount calculated according to the scheduled benefit. It combines the DC (benefit value is defined based on the individual account balance) and $\mathrm{DB}$ (costing is collective) characteristics, thus having the VC characteristics presented by the legislation (CGPC, 2005). This is a peculiarity found in the RPC and present, for example, in the Funpresp-Exe regulations.

The participant periodically accumulates a social security contribution determined according to the contribution percentage $(c)$ of the participation salary $\left(S_{0}\right)$. The total amount contributed during the accumulation period is used, mainly, to fund the normal retirement benefit (DC). However, under the amount contributed, there is a rate $(\tau)$ responsible for defraying unscheduled benefits. Thus, the contribution amount destined to fund the unscheduled benefits is $S_{0} \cdot c \cdot \tau$ and is allocated to a collective account of the plan participants, leaving the accumulation in the participant's reserve (RI) the value of $S_{0} \cdot c \cdot(1-\tau)$, used to pay the DC benefit.

The contribution rate $\tau$ is expected not to be excessive to the point of compromising the participant's income and normal retirement, nor be insufficient, generating financial imbalance during the payment of unscheduled benefits, guaranteeing the participant's interest and the pension fund. Determining the $\tau$ rate responsible for honoring pension commitments is one of the significant interests of the actuarial sectors of pension funds, which arouses the interest of academia and guides the efforts of this work.

Considering the interest rate $i$, the wage growth rate $j$, the initial participation salary $S_{0}$, the contribution percentage $c$ and, also, the $\tau$ rate, it is possible to determine the present value of the contributions (VPC) destined to cover the unscheduled benefits obtained by accumulation over T periods (Giambiagi \& Afonso, 2009), presented in Equation 1.

$$
\operatorname{VPC}(c, \tau)=\sum_{k=x+1}^{T+x} \frac{c \cdot \tau \cdot S_{0}(1+j)^{k-x} \cdot(1+i)^{(T+x-k)}}{(1+i)^{T}}
$$

In social security, the receipt of contributions is conditional on the participant's survival to decreases in death and disability in a multiple-decrement manner. Thus, there is no certainty about the future payment of contributions (Dickson, Hardy, Hardy, \& Waters, 2013). To incorporate such uncertainty, consider ${ }_{h} p_{x}^{\left({ }^{(m o r i n v)}\right)}$ the probability that the beneficiary will survive the decreases in death and disability between $x$ and $h$. The present value of contributions at the moment the participant is $x$ years old and paid for $T$ periods, considering such uncertainty, is:

$$
V P C(c, \tau)=\sum_{k=1+x}^{T+x} \frac{{ }_{k} p_{x}^{(m o r, i n v)} \cdot c \cdot \tau \cdot S_{0}(1+j)^{k-x} \cdot(1+i)^{(T+x-k)}}{(1+i)^{T}}
$$

Similarly, we can define the present value of the benefit ( $V P B$ ) of value $A$, paid for $N$ periods, and started $T$ periods after age $x$ of the participant.

$$
V P B={ }_{T+x} p_{x}^{(m o r, i n v)}\left[\sum_{k=T+x+1}^{T+x+N} \frac{{ }_{k}^{(m o r)} \cdot A}{(1+i)^{k-x}}\right]
$$

For benefits, either the participant is already retired (exposed only to the decrease in death) or has passed away, and the dependent is exposed only to the decrease in death, with the single-decrement term ${ }_{k} p_{T+x}^{(m o r)}$ for the death. The biometric table for ${ }_{k} p_{T+x}^{(m o r)}$ depends on the type of benefit: normal retirement (participant's table), disability retirement (death table for the disabled), and pension (dependent table). However, to start receiving at
$T+x+1$, the participant must have survived death and disability between $x$ and $T+x$, represented by ${ }_{T+x} p_{x}{ }^{(m o r i n v)}$. The values of $T$ and $N$ are known only when the benefit is for normal retirement. For the others (unscheduled benefits), these amounts depend on the type of benefit and when the participant's death or disability occurs. The payment periods of the benefits, the biometric tables, and the values of the benefits depend on the regulation of the pension plan, detailed in the application presented in section 4.

The difference between $\operatorname{VPC}(c, \tau)$ and VPB is called net actuarial income and is presented in Equation 4 using the English term NET. The deficit situation is characterized when the future flow of benefit payments is greater than the amount contributed. Otherwise, the 
result is said to be a surplus, i.e., the amount accumulated by the receipt of contributions is more than sufficient to pay the benefits.

$$
N E T(c, \tau)=V P C(c, \tau)-V P B
$$

The actuarially fair rate $\tau^{*}$ (Queisser \& Whitehouse, 2006) is determined between the two situations, i.e., the value $\tau^{*}$ so that the actuarial NET (Equation 4 ) is equal to zero $\operatorname{NET}\left(\mathrm{c}, \tau^{*}\right)=0$. In the literature, $\tau^{*}$ is calculated disregarding the probabilistic factors of mortality and disability (Fernandes \& Gremaud, 2003; Giambiagi \& Afonso, 2009), using the average of future flows, the time of receiving the benefit (Oliveira, Beltrão, \& Maniero, 1997), applying only the decrements for death (Freire \& Afonso, 2015; Rodrigues \& Afonso, 2015; Souza, 2018), and using multiple decrements for actuarial profiles in the RGPS (Gouveia et al., 2018; Martins \& Campani, 2019) and the RPPS (Corrêa, 2018). In all of these references, the rates are determined for benefits generated exclusively from the DB or DC modality, without considering the particularities of unscheduled benefits that have, for example, benefits generated due to the participation salary and the DC benefit.

Given the heterogeneity of the participants and the types of benefits, it is possible to determine the actuarially fair rates classified by profile and source of social security costs. With this, the value of the specific balance rates is determined by solving Equation 5 to minimally guarantee the total costing of future benefits, considering the participants' profiles' distribution. Thus, the specific balance rate is determined by the lowest rate with which the actuarial NET is greater than or equal to zero for a specific social security cost source, given the composition of the participants according to actuarial profiles. In this strategy, the specific actuarial nature of each benefit is respected, in addition to ensuring greater transparency and management of future obligations. Thus, the specific balance rate $\left(\bar{\tau}_{a}\right)$ for the benefit $a$ is that ensuring that the aggregate actuarial $\operatorname{NET}\left(c, \bar{\tau}_{a}\right)$ of the participants of all $G$ actuarial profiles is greater than or equal to zero.

$$
\begin{gathered}
\underset{\bar{\tau}_{a}}{\operatorname{argmin}}\left(\bar{\tau}_{a}\right)=\left\{N E T\left(c, \bar{\tau}_{a} \mid 0 \leq N E T\left(\mathrm{c}, \bar{\tau}_{a}\right)<N E T\left(\mathrm{c}, \tau_{a}\right), 0 \leq \tau_{a} \leq 1, a \in 1,2, \cdots, H\right\}\right. \\
\operatorname{NET}\left(\mathrm{c}, \bar{\tau}_{a}\right)=\sum_{z=1}^{G} M_{z} \times N E T_{z}\left(c, \bar{\tau}_{a}\right) \\
\tau=\sum_{a=1}^{H} \bar{\tau}_{a}
\end{gathered}
$$

where $M_{z}$ is the relative percentage of participants with profile $z, N E T_{z}\left(c, \bar{\tau}_{a}\right)$ the actuarial NET of profile $z$ with the rate $\bar{\tau}_{a}, H$ the number of actuarial rates and $G$ the number of actuarial profiles.

The proposed methodology allows the actuarial balance of each type of unscheduled benefit, solving Equation 5, to guarantee the total balance of the plan. The general balance rate $(\tau)$ is formed by the marginal costs independent of each cost source, indicated by Equation 7 .
It is possible to consider situations in which the surplus of one rate compensates for the deficit of another one. However, this strategy will not be considered in this work. Also, given the collective nature of the collective costing benefits, the possible difference between the actuarially fair rate $\tau^{*}$ of each actuarial profile and the balance rate $\bar{\tau}_{a}$ adopted for all participants and Donnelly (2015) is addressed in this work as solidarity between members.

\section{FUNPRESP-EXE CASE}

This section details the legal, actuarial, and demographic assumptions required to apply the proposed methodology in Funpresp-Exe's unscheduled benefits.

\subsection{Social Security Benefits}

Funpresp-Exe offers DC benefits, for normal retirement and $\mathrm{DB}$ and $\mathrm{VC}$ benefits, for benefits related to disability retirement and pensions. Unscheduled benefits before the normal retirement date are determined according to the participant's salary (DB). In contrast, unscheduled benefits after the normal retirement date are linked to the DC (VC) benefit.

The public worker's account balance is formed by the sum of the contributions determined according to the contribution $(c)$ of the participation salary $\left(S_{0}\right)$, 
which is the value of the salary that exceeds the RGPS ceiling. For example, if the ceiling is $\mathrm{R} \$ 6,000$ and the participant receives $R \$ 10,000$, the value of the participation salary is $\mathrm{R} \$ 4,000$. The government worker can choose to contribute with $c=\{7.5 \%, 8.0 \%, 8.5 \%\}$ of the participation salary. Such percentages are defined by law and represent the limits for the sponsor's equal contribution. The sponsor's contribution guarantees the Union's payment of $R \$ 1$ for each $R \$ 1$ paid by the worker. A rate funds the unscheduled benefits of Funpresp-Exe, currently, $\tau=17.95 \%$. This is levied on the amount contributed to the plan, earmarked for the collective account balance $S_{0} \cdot c \cdot(0.1795)$ and the individual balance $S_{0} \cdot c \cdot(1-0.1795)$.

To facilitate understanding the benefits of FunprespExe, Figure 1 presents a scheme with the events that generate such benefits. The horizontal lines are time points when the worker participates in the plan, or there is a benefit being paid to the dependent. The participant is exposed to death and/or disability risks, generating benefits not scheduled in the plan. Large circles with Roman numerals indicate when the benefit starts or ends. Vertical lines represent the occurrences of these events, and acronyms represent the benefits.

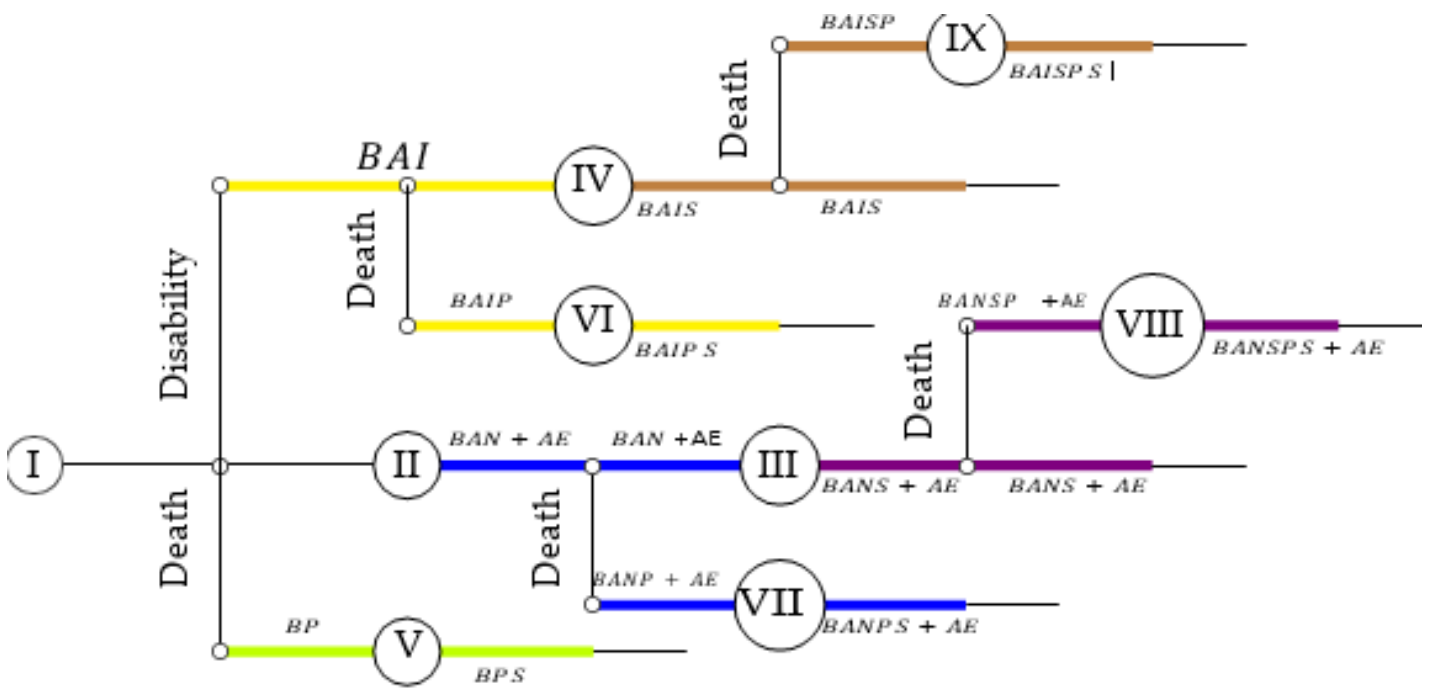

Figure 1. Flow of events and time points of payment of benefits.

Note: I: entry of the participant in the plan; II: age foreseen in the legislation for retirement; III: life expectancy of the participant at the beginning of normal retirement; IV: life expectancy of the participant determined at the beginning of retirement due to disability; V: life expectancy of the active participant, if he had not died; VI: life expectancy of the participant, in retirement due to disability, who died before life expectancy on the date of retirement due to disability; VII: life expectancy of the participant, in normal retirement, who died before life expectancy on the date of normal retirement; VIII: life expectancy of the participant, in normal retirement, who died after exceeding life expectancy on the date of normal retirement; IX: life expectancy of the participant, in retirement due to disability, who died after exceeding life expectancy on the date of retirement due to disability.

Source: Prepared by the authors.

The main Funpresp-Exe liability benefit is the Normal Retirement benefit (BAN) payment when the participant is entitled to receive a monthly income between II and III, as shown in Figure 1. The AN benefit is calculated through $B A N=\frac{R I+A E}{F\left(i, e^{(0)}\right)}$. RI is the individual reserve, $e^{(0)}$ the participant's life expectancy on the retirement date, AE the Extraordinary Contribution (if the participant is entitled to it), and $F($.$) the factor that turns the reserve at the time$ of retirement into a benefit paid until the expectation of survival in an annuity (Dickson et al., 2013), considering the interest rate $i$. As it is a DC benefit, the actuarial balance of the BAN is not affected by changes in the demographic distribution of the workforce, as the amount of the benefit is calculated and periodically updated, according to the accumulated account balance and life expectancy of the participant (Law n. 12,618, 2012). However, all DB benefits after retirement depend on the BAN amount, and, therefore, changes in the RPPS retirement criteria are reflected in the complementary retirement of the government worker.

Extraordinary Contribution (AE) has exclusive characteristics and, for some careers of civil workers, increases the value of the individual account balance inversely proportionally to the contribution time required for retirement. This benefit provides primary school teachers and female government workers, for example, with an increase in the retirement benefit based on the 
$35 / \mathrm{T}$ ratio, with $\mathrm{T}$ being the length of service required for retirement in the RPPS (Law n. 12,618, 2012). The main objective of AE is to increase the value of the BAN. However, as all unscheduled benefits after retirement depend on the BAN amount, all benefits after II have an associated $\mathrm{AE}$ benefit. The methodology proposed in this work considers actuarial analysis classified by actuarial profile, which allows pension plans similar to Funpresp-Exe to be modeled with greater ease.

$$
B P=\max \left\{\left[\operatorname{Average}\left(B C_{80 \%}\right)-R P P S\right] \cdot \frac{\% M C}{8.5 \%} \cdot 70 \% ; 2 \cdot U R P\right\}
$$

where "Average (BC80\%)" is the arithmetic average of the $80 \%$ highest remuneration, RPPS the benefit received by the official social security, MC the average of the contribution rates - which can vary between $7.5 \%, 8.0 \%$, and $8.5 \%$ - and URP the Plan Reference Unit. The amount considered in this work for URP is R $\$ 100$. In addition to
If the public worker passes away before II, dependents are entitled to receive the pension benefit for the death of the active participant (BP), between the death of the participant and V, as shown in Figure 1. BP value is determined according to the difference between the worker's average $80 \%$ higher wages and the amount paid by the RPPS. However, for this benefit, there is a $70 \%$ reduction. BP is calculated by:

$$
B A I=\max \left\{\left[\operatorname{Average}\left(B C_{80 \%}\right)-R P P S\right] \cdot \frac{\% M C}{8.5 \%} ; 2 \cdot U R P\right\}
$$

Table 1 summarizes the terms, calculation, and costing rate of the benefits presented in Figure 1. It shows that all benefits derive from the calculation of BAN, BP or $\mathrm{BAI}$, and $\mathrm{AE}$ (if the participant is entitled). Additionally, extending the concept of modality adopted for the scheduled benefit to the other unscheduled benefits, the benefit is informed as DB, DC, and VC. Before normal retirement $(\mathrm{AN})$, all benefits are $\mathrm{DB}$, and after $\mathrm{AN}$, they are VC. For more information, it is possible to consult the Funpresp-Exe regulations (Funpresp, 2013).

Table 1

\begin{tabular}{|c|c|c|c|c|c|c|}
\hline Benefit & Acronym & Start & Term & Formula & Rate & Characteristic \\
\hline Normal Retirement & BAN & II & III & $\frac{R I+A E}{F\left(i, e^{(0)}\right)}$ & $\mathrm{AL} \_\mathrm{AN}\left(\tau_{4}\right)$ & $\begin{array}{l}\mathrm{DC} \text { for } \mathrm{RI} \text { and } \mathrm{VC} \\
\text { for } \mathrm{AE}\end{array}$ \\
\hline BAN Pension & BANP & Death & VII & $70 \% \mathrm{BAN}$ & $\mathrm{AL} \_\mathrm{AN}\left(\tau_{4}\right)$ & VC \\
\hline BANP Survival & BANPS & VII & Lifetime & $80 \%, 70 \%$ BAN & $\mathrm{AL} \_\mathrm{AN}\left(\tau_{4}\right)$ & VC \\
\hline Extraordinary contribution & $\mathrm{AE}$ & II & Lifetime & $\mathrm{RI}\left(\frac{35}{T}-1\right)$ & $\begin{array}{c}\text { AL_AN }\left(\tau_{4}\right), \\
\operatorname{AL}_{-} \operatorname{ANBSA}\left(\tau_{5}\right)\end{array}$ & VC \\
\hline BAN Survival & BANS & III & Lifetime & $80 \%$ BAN & $\mathrm{AL} \_$ANBSA $\left(\tau_{5}\right)$ & VC \\
\hline BANS Pension & BANPS & Death & VIII & $70 \%, 80 \%$ BAN & $\mathrm{AL} \_$ANBSA $\left(\tau_{5}\right)$ & VC \\
\hline BANS Survival & BANSPS & VIII & Lifetime & $\begin{array}{c}80 \%, 70 \%, 80 \% \\
\text { BAN }\end{array}$ & $\mathrm{AL}_{-} \mathrm{ANBSA}\left(\tau_{5}\right)$ & VC \\
\hline Pension & $\mathrm{BP}$ & Death & V & Equation 8 & AL_AT $\left(\tau_{1}\right)$ & DB \\
\hline BP Survival & BPS & V & Lifetime & $80 \% \mathrm{BP}$ & AL_AT $\left(\tau_{1}\right)$ & DB \\
\hline Disability retirement & BAI & Disability & IV & Equation 9 & $\mathrm{AL} \_\mathrm{Al}\left(\tau_{2}\right)$ & DB \\
\hline BAI Pension & BAIP & Death & $\mathrm{VI}$ & $70 \% \mathrm{BAI}$ & $\mathrm{AL} \_\mathrm{Al}\left(\tau_{2}\right)$ & DB \\
\hline BAIP Survival & BAIPS & $\mathrm{VI}$ & Lifetime & $80 \%, 70 \% \mathrm{BAI}$ & $\mathrm{AL} \_\mathrm{Al}\left(\tau_{2}\right)$ & DB \\
\hline BAI Survival & BAIS & IV & Lifetime & $80 \% \mathrm{BAI}$ & $\mathrm{AL} \_\mathrm{AIBSA}\left(\tau_{3}\right)$ & DB \\
\hline BAIS Pension & BAISP & Death & IX & $70 \%, 80 \% \mathrm{BAI}$ & $\mathrm{AL} \_\mathrm{AIBSA}\left(\tau_{3}\right)$ & DB \\
\hline BAISP Survival & BAISPS & IX & Lifetime & $\begin{array}{c}80 \%, 70 \%, 80 \% \\
\text { BAI }\end{array}$ & AL_AIBSA $\left(\tau_{3}\right)$ & DB \\
\hline
\end{tabular}

Summary of the benefits of Funpresp-Exe

Source: Prepared by the author based on the Funpresp-Exe regulation. 
For all unscheduled benefits to be honored by the entity, a specific rate is attached to each of them. All plan contributors pay this rate during the accumulation phase. Four profiles of statutory federal workers (male teacher, female teacher, male government worker, and female government worker) and five rates to cover unscheduled benefits are considered, as shown in Table 1. The rates are AL_AT $\left(\tau_{1}\right), \operatorname{AL} \_\mathrm{AI}\left(\tau_{2}\right), \mathrm{AL} \_\mathrm{AIBSA}\left(\tau_{3}\right), \mathrm{AL} \_\mathrm{AN}$ $\left(\tau_{4}\right)$, and AL_ANBSA $\left(\tau_{5}\right)$. It is essential to highlight that the intervals of the sum of the actuarial NET of each rate (equations 2 and 3 ) depend on the type of benefit and the actuarial profile. They are represented in Figure 1 and detailed in equations $12,13,14,15$, and 16 , respectively, in Appendix A of this work.

Also, some of these benefits are contingent on the occurrence of a decrease. For example, to calculate the actuarial NET at time point $x$ of the disability retirement benefit (BAI) started at age $t$, the probability ${ }_{h} p_{x}^{(m o r)}$ of Equation 3 is the probability that the disabled worker will remain alive, considering the life table for the disabled ${ }_{h}^{i n v} p_{x}^{(m o r)}$. Also, it is necessary to multiply the value found in Equation 3 by the probability that the participant has survived the decreases in death and disability until before age $t$. Finally, it is also necessary to multiply by the probability that the participant will become disabled at age $t\left(q_{t}^{(i n v)}\right)$, as presented in Equation 14 in Appendix A. Concerning the probabilities ${ }_{h} p_{x}^{(m o r)}$, in the case of pensions, when the participant has passed away, the receipt of the benefit is conditional on the probability that at least one family member is alive (Funpresp, 2013).

These benefits are initially funded by the amount accumulated in the participant's reserve and, if they are not sufficient, by the common fund (Funpresp, 2013). Thus, these benefits are subject to a deficit in actuarial imbalance, changes in the RPPS legislation, changes in the participants' demographics, or if the rate is insufficient for the costing.

The following section presents the main changes in the social security legislation of interest to the RPC and the legal assumptions considered for this application.

\subsection{Legal Assumptions}

Although the unscheduled benefits are the responsibility of Funpresp-Exe, the amounts depend on parameters established by the RPPS, which were changed by EC $n .88$ and, more recently, by EC n. 103. While EC n. 88 was in force, the value of the benefits in the RPPS of retirement due to disability and the pension value due to death of the active participant were equal to the last active salary, limited by the RGPS ceiling. The age retirement criteria were 65 years for men, 60 years for women, and five years less for each sex if the worker was a primary school teacher. The other eligibility conditions were: contribution time of 35 and 30 years for men and women, respectively, and ten years of service. After EC n. 103, the retirement age for female workers becomes 62 , and 57 for female teachers.

Also, the amount paid by the RPPS for retirement benefits due to disability and pension due to death of the active participant after EC n. 103 will depend, if not associated with work activities, on the contribution time. As we will see below, the changes to disability and pension indirectly generate the most significant impacts on Funpresp-Exe rates, as the BP and BAI benefits depend on the amount paid by the RPPS.

Finally, it is assumed that the public worker requests retirement when they reach retirement age in both legal situations.

\subsection{Biometric Assumptions}

Funpresp-Exe uses the RP-2000 life table, applying the actuarial reduction that corrects the temporal evolution of the probability of death (Funpresp, 2015). The methodology and the time correction data can be found in Actuaries (2000).

In this work, two RP-2000 mortality tables will be compared, the first from 2015 (after this, RP), the reference date of the analyses, and the second 20 years later (called $\mathrm{RP}+20)$, i.e., with the projection of mortality probabilities as of 2035. Considering the $\mathrm{RP}+20$ table, there is an increase of 1.61 years in men's life expectancy at 60 years of age and an increase of 1.46 years at 65 . The first increase is essential for teachers and the second for other workers. The increase is 0.95 years at 55 years of age and 0.92 years at 60 years of age for women. Similarly, the first increase is essential for teachers and the second for other workers. The differences between the expectations of survival in the two tables will be used to assess the sensitivity of changes in the probabilities of mortality in calculating the fair and balance rates.

Funpresp-Exe adopts the table presented in Cardoso (2013) for the probability of entering disability. In addition to mortality and disability, using a database for mortality among the disabled is required. The probability of mortality among the disabled for different ages of entry into disability is given by Ribeiro (2006).

The mortality and disability tables independently model the likelihood of a change in the participant's "active" status. This is a single-decrement approach, in which there is only one decrease, experiencing the 
participant's active situation. However, such factors act concurrently, i.e., there is more than one factor trying to prevent the public worker from remaining in the "active" status. Thus, the permanence in the contribution situation has multiple decreases. Given the occasional inexistence or unavailability of access to data, it is possible to obtain tables with multiple decrements. The steps are detailed by Castro (1997), using the single-decrement probabilities and considering the hypothesis of uniform occurrence of the decrements (Pinheiro, 2005).

\subsection{Demographic Assumptions}

As presented in previous sections, in addition to actuarial decreases, the calculation of the costing rates for unscheduled benefits involves other factors, such as wage growth rate and composition of the workforce according to sex, entry age into the RPC and occupation.

In this work, such premises were determined using the administrative records available in the Annual List of Social Information (Rais), responsible for consolidating the data of the formal work. For a version of this data with access to the worker's identification records, Santos et al. (2018) identify inconsistencies and propose corrections to determine the number of public workers at the level of the federated entity. However, Rais's public base records used in this article are unidentified and are used only for national estimates. Despite the possibility of inconsistency, the use of data at an aggregated, relative, and national level is not compromised, according to the Ministério do Trabalho e Previdência Social (2016). Also, the results of this database were used to determine the relative quantities of the mass of workers according to the actuarial profile and national annual wage growth rates.

The records of civil workers linked to federal-level agencies and under the statutory regime with admission date in the public service after 2004 were considered. Civil workers were classified according to the regime type: those with a salary below the official social security ceiling being RPPS and the other ones, RPC. Also, records in the database linked to fire brigades, military police, and armed forces were excluded. Elementary education workers were identified using codes 231, 232, and 233 for the subgroup in the Brazilian Classification of Occupations (CBO).

The relative frequencies $M_{z}$ of the actuarial profiles, presented in Equation 6, are determined by the workers' combination of sex and occupation. Two scenarios were created to assess the sensitivity of the rates to changes in $M_{z}$. The first $M_{z}$ distribution is formed by the relative percentage of workers eligible for the Funpresp-Exe plan in Rais in 2015 (stock base). The second $M_{z}$ configuration will be formed by the average relative distribution of workers eligible for Funpresp-Exe, with an admission date between 2015 and 2017, called the entry base.

Part (a) of Figure 2 shows the number of civil workers in the public service segregated by age in each actuarial profile in 2015 (stock base). It is possible to notice a modal distribution close to 35 , with an average close to 37 years. Based on part (b) of Figure 2, the distribution of workers that enter the public service (entry base) and eligible for $\mathrm{RPC}$ is asymmetric on the right, with a mode close to the age of 30 and an average close to 35 years. The stock base has less than $8 \%$ of education professionals, while the entry flow base has more than $13 \%$.

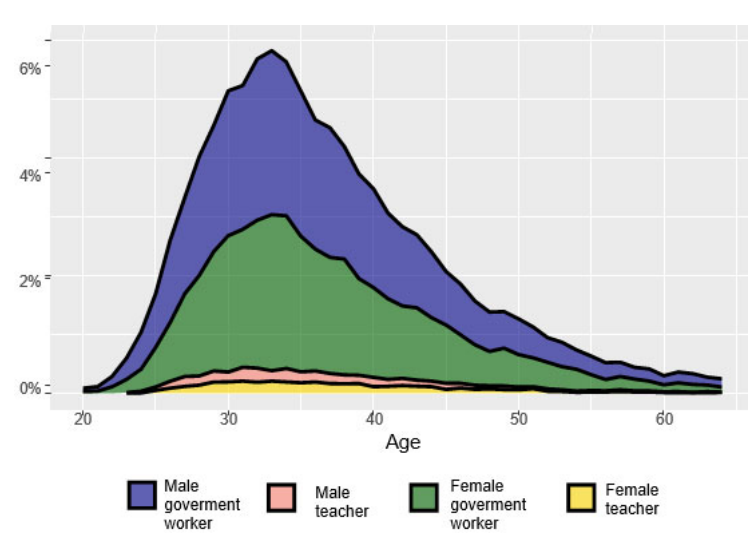

a) Age distribution of participants in the flow pattern of the stock base.

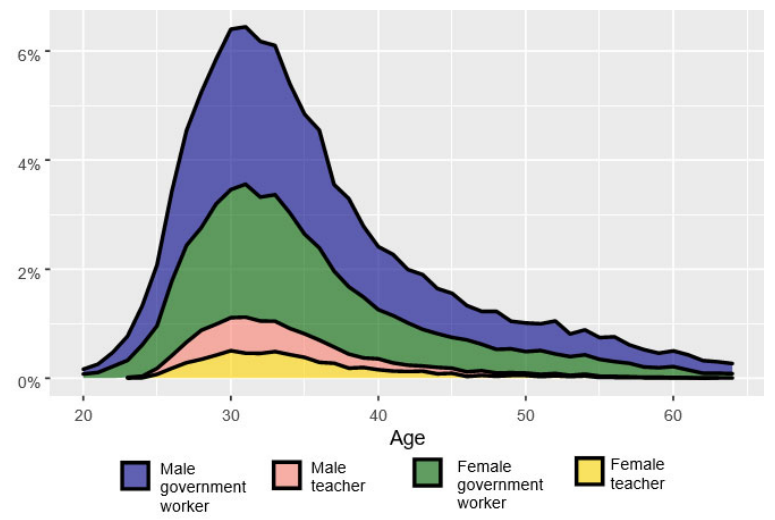

b) Age distribution of participants in the flow pattern of the entry flow base.

Figure 2. Distribution of the eligible records by the actuarial profile in the Annual List of Social Information (Rais) 2015. The stock records are those in the base at the beginning of 2015 and remained until the end of 2015. The entry flow base considers the average percentage of records entered between 2015 and 2017 and remained until the end of each period.

Source: Prepared by the authors based on data from the Annual List of Social Information. 
Rais's database was also used to calculate annual salary growth rates by actuarial profile. The records remaining in their positions until the end of each year analyzed and with a service length compatible with the entry into 2006 were considered. This is done, for example, by filtering records from 2006 that have less than one year of time of service. For 2007, the records are between 1 and 2 years old and so on until 2017, leaving just over 90 thousand records every year. With the values of wages deflated by 2006 IPCA, the average national wage growth for each profile was estimated using the model $E(S \mid A)=S_{2006}+w \times A$. $\mathrm{S}$ is the estimated real wage, $A$ the number of the year (starting from 0 to 2006), $w$ the real annual wage growth, and $S_{2006}$ the starting wage in 2006. Unlike the proposal presented by Giambiagi and Afonso (2009), with wages in geometric progression, this work adopts the arithmetic progression for real wages. Thus, the rate of real wage growth, presented in Equation 2 by j, is not constant and is calculated by $\mathrm{j}_{\mathrm{t}}=\frac{w}{S_{2006}+w \cdot t}$, where $t$ the time point of analysis after entering the public service, $S_{2006}$ the starting wage, and $w$ real gross growth per year. Table 2 presents the model estimates for the calculation of $\mathrm{j}_{\mathrm{t}}$.

Table 2

Average starting salary in reais $(R \$)$ and gross average annual growth per actuarial profile

\begin{tabular}{ccccccc}
\hline & & \multicolumn{2}{c}{ Starting wage $\left(\boldsymbol{S}_{\mathbf{2 0 0 6}}\right)$} & \multicolumn{2}{c}{ Increase $(\mathbf{w})$} \\
\hline Occupation & Regime & Male & Female & Male & Female \\
\hline Education & $\mathrm{RPPS}$ & $\mathrm{R} \$ 1,521.02$ & $\mathrm{R} \$ 1,455.51$ & $\mathrm{R} \$ 70.08$ & $\mathrm{R} \$ 70.56$ \\
\hline Education & $\mathrm{RPC}$ & $\mathrm{R} \$ 4,576.85$ & $\mathrm{R} \$ 4,524.39$ & $\mathrm{R} \$ 83.86$ & $\mathrm{R} \$ 82.16$ \\
\hline Other & $\mathrm{RPPS}$ & $\mathrm{R} \$ 1,293.67$ & $\mathrm{R} \$ 1,362.26$ & $\mathrm{R} \$ 56.22$ & $\mathrm{R} \$ 48.33$ \\
\hline Other & $\mathrm{RPC}$ & $\mathrm{R} \$ 5,670.53$ & $\mathrm{R} \$ 5,203.16$ & $\mathrm{R} \$ 23.57$ & $\mathrm{R} \$ 20.23$ \\
\hline & $\mathrm{RGPS}$ ceiling & & $\mathrm{R} \$ 2,577.54$ & & \\
\hline
\end{tabular}

Note: Deflated values (IPCA) for 2006. Regime of Social Security for Public Servants (RPPS). Complementary Pension Regime (RPC).

Source: Prepared by the authors based on data from the Annual List of Social Information.

The results show that education professionals have lower starting salaries in the RPC than other professionals $\left(S_{2006}\right)$ but higher annual growth, identified by the slope $(w)$. For the same period and reference date, the social security ceiling has an estimated initial value of $\mathrm{R} \$$ $2,577.54$ and an increase of $\mathrm{R} \$ 20.23$. In 2006, the deflated pension ceiling observed was $\mathrm{R} \$ 2,586.92$.

EC n. 103 establishes conditions to determine the value of retirement benefits due to disability and pension due to the death of an active participant. When the death or disability of the active participant occurs during work activity or on the home-to-work way, the benefit of the RPPS is full. Otherwise, it is proportional to the contribution time. Using Rais's records, $11.85 \%$ of the cases of disability were estimated to be related to the worker's duties, while death is only $1.05 \%$ of the cases.

Pension benefits depend on the participant's family composition. This work considers a standard family with a father, mother, and two daughters. The two daughters are a conservative criterion since women's table has a longer life expectancy. The man is three years older than the woman, the first daughter being born at 30 and the second at 32 years of the mother's age (Gouveia et al., 2018). The rules for the right to receive a spouse's pension are the same as for the RPPS, and the children receive up to 21 years. The entry age into the labour market is the minimum between the entry age into the RPC, with scenarios from 20 years old and 25 years.

\section{RESULTS}

The results of this work are directed to the sensitivity analysis of the actuarially fair rates, expressed in Equation 4, and balance rates, expressed in Equation 7, of the unscheduled benefits of the Funpresp-Exe pension plan considering scenarios of legal, biometric, and demographic changes.
For the calculations carried out below, the basic interest rate of $i=4 \%$ per year (the same adopted by the fund) and the inflation index of the Broad Consumer Price Index (IPCA) to correct financial values are considered. For simplification, but without loss of generality, the contribution payments and the receipt 
of benefits consider annual intervals. The reference date used for the analysis of the results is January 2015 and coincides, on purpose, with the start of the fund's activities.

\subsection{Actuarially Fair Rate}

Figure 3 shows, for each actuarial profile (combination of entry age, sex, and occupation), the balance rates for legal changes (EC n. 88 and EC n. 103) and biometric changes (RP and RP+20), identified by combining line type and color, respectively.

Graph (a) in Figure 3 shows that the account balance can cover almost entirely the benefits of the $\mathrm{AL} \_\mathrm{AN}$ rate for profiles that do not have $\mathrm{AE}$ (extraordinary contribution). The balance is little affected by the participant's entry age, as evidenced by the slight slope of the actuarially fair rate over the ages of entry. This occurs as the benefit depends on the BAN amount (normal retirement benefits), determined based on the accumulated RI, DC benefit. However, it is a benefit that has a rate that is sensitive to changes in the composition of workers, as it changes for each profile due to the difference between the retirement ages and different levels of AE benefit. The change in legislation (continuous and dotted lines) has only slightly changed the value of the actuarially fair rates for women. This rate is very little affected by biometric changes (blue and red) in any scenario.

Concerning AL_ANBSA, graph (b) in Figure 3 shows that the rate needed to defray the actuarial demand related to the survival benefit is little influenced by the entry age of the participant, since, as in AL_AN, the benefits of this rate are determined after calculating the normal retirement amount and based on RI. Also, the social security reform of EC n. 103 affected only the rates of female workers and teachers.

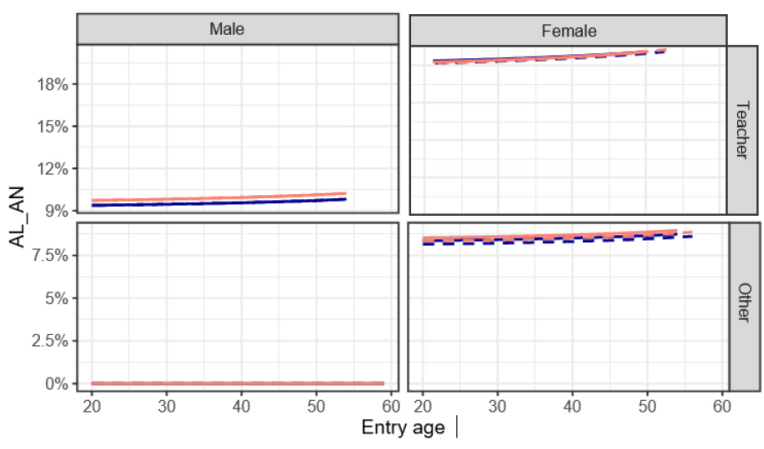

- RP+20 and $\mathrm{C} 88$ - $\mathrm{RP}$ and $\mathrm{EC} 88$ - . RP+20 and EC103 - "RP and EC103

a) Actuarially fair rate for benefit costing during normal retirement ( $\mathrm{AL} \_\mathrm{AN}$ ).

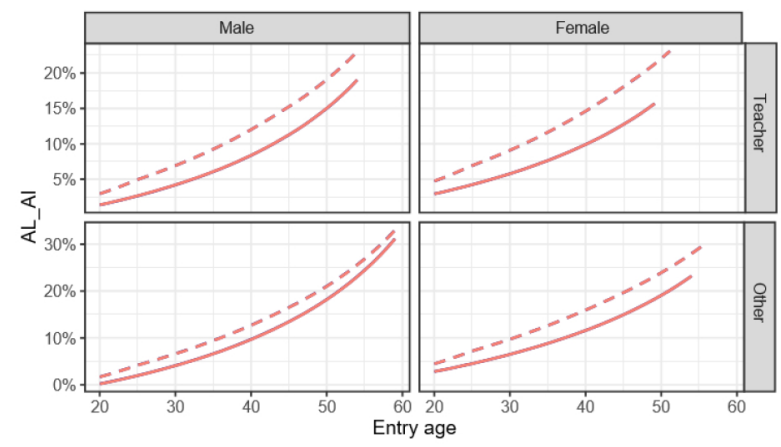

- RP+20 and $\mathrm{C} 88$ - RP and EC88 - - RP+20 and EC103 - - RP and EC103

c) Actuarially fair rate for benefit costing during disability retirement (AL_AI).

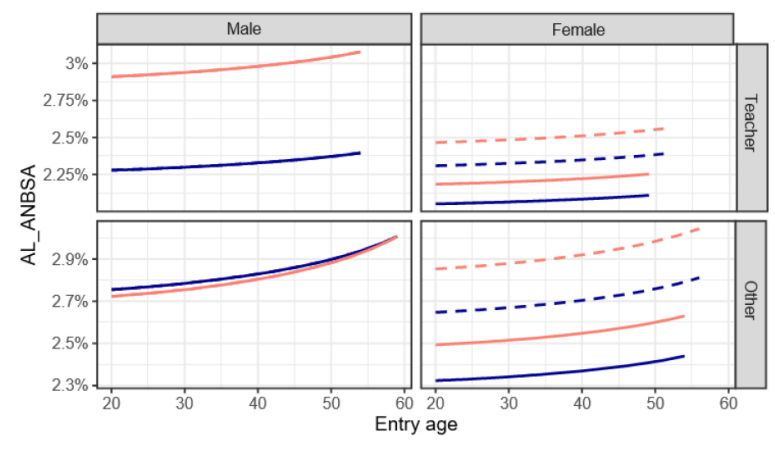

- RP+20 and C88 - RP and EC88 - - RP+20 and EC103 - RP and EC103

b) Actuarially fair rate for benefit costing during the normal retirement survival benefit

(AL_ANBSA).

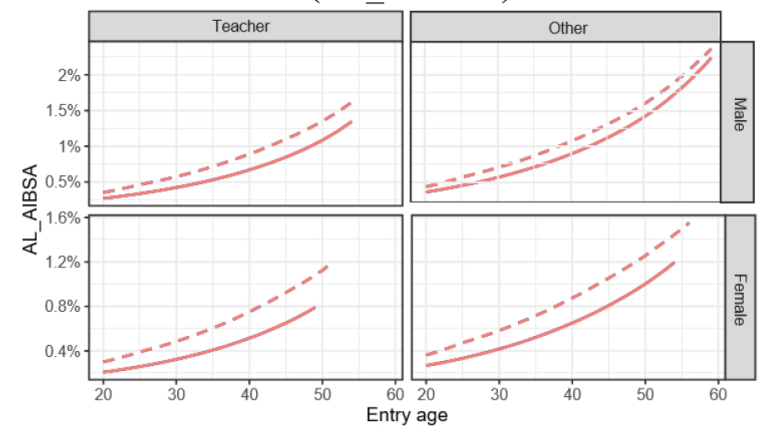

- $\mathrm{RP}+20$ and $\mathrm{C} 88$ — RP and $E \mathrm{C} 88$ - . RP+20 and $E \mathrm{C} 103$ - . RP and $E \mathrm{C} 103$

d) Actuarially fair rate for benefit costing during disability retirement survival benefit (AL AIBSA).

Figure 3. Actuarially fair rate $\tau^{\star}$ for unscheduled benefit costing considering different actuarial profiles, formed by the combination of entry age into the RPC, sex, and occupation (teacher or not) of the participant. 


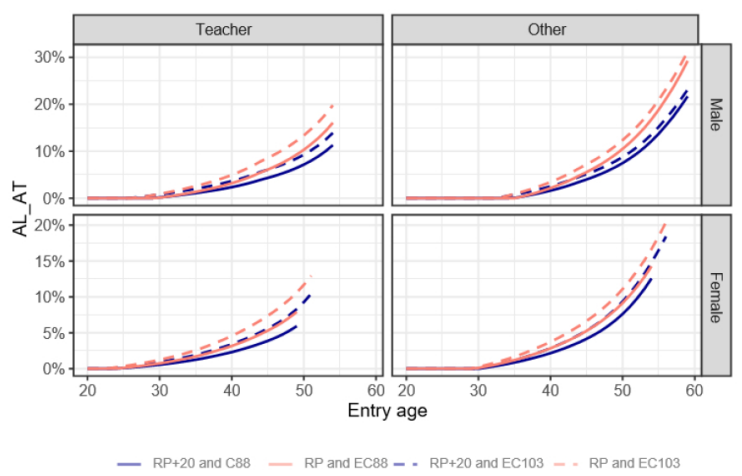

e) Actuarially fair rate for benefit costing during the pension due to the death of an active participant (AL_AT).

Figure 3. Cont.

Source: Prepared by the authors.

Graph (c) in Figure 3 indicates that the actuarially fair rate of benefits related to disability retirement (AL_AI) increases according to the increase in the entry age into the RPC. This results from the increased probability of disability at older ages and the low individual reserve amounts for those who enter the RPC late. Also, the pension reform severely affected the benefit. There is a gap widening between the average remuneration and the amount paid by the RPPS, as presented in Equation 9. These results suggest the need, as in EC n. 103, to consider the contribution time to determine the value of the BAI benefit and, thus, reduce the disparity between the social security costs of civil workers with different entry ages into the plan.

Graph (d) in Figure 3 indicates that the rate needed to defray the actuarial demand related to the disability retirement survival benefit (AL_AIBSA) depends on the participant's entry age and is sensitive to legislation changes. This occurs as this rate's benefits depend on the amount paid on disability retirement (BAI), which, in turn, is determined according to the amount paid by the RPPS.

Finally, the analysis of graph (e) in Figure 3 and AL_AI shows that the fair rate for AL_AT is higher for workers that enter the RPC late. It is also possible to notice a reduction in the rate value when there is an increase in life expectancy, observed by the difference between the RP and RP-20 tables. Also, the pension reform requires a more significant collective effort to cover the benefits of the AL_AT rate since EC n. 103 increased the difference between the worker's salary and the amount paid by the RPPS for the active participant's death pension.

\subsection{Balance Rates}

While the classification by cost source and actuarial profile allows specific analyses of the actuarially fair rates, the unscheduled benefits are paid collectively through the balance rate, proposed in this work by solving equations 5,6 , and 7 .

Table 3 presents, in aggregate form, the general balance rate for the two databases, with the different biometric tables and changes in the legislation. Also, the results are presented for different percentages of contributions $c=\{7.5 \%, 8 \%, 8.5 \%\}$. The balance rates are indifferent to the percentage of contribution $(c)$ levied on the worker's participation salary. Thus, the participant's decision does not affect the balance of the plan, i.e., the participants receive unscheduled social security benefits in proportion to the chosen contribution percentage. 
Table 3

General balance rate $\tau(\%)$ for funding the plan's unscheduled benefits, classified by stock configuration and worker entry

\begin{tabular}{|c|c|c|c|c|c|c|c|c|}
\hline \multirow{3}{*}{ c $(\%)$} & \multicolumn{4}{|c|}{ Stock } & \multicolumn{4}{|c|}{ Entry flow } \\
\hline & \multicolumn{2}{|c|}{ EC n. 88} & \multicolumn{2}{|c|}{ EC n. 103} & \multicolumn{2}{|c|}{ EC n. 88} & \multicolumn{2}{|c|}{ EC n. 103} \\
\hline & $\mathrm{RP}+20$ & $\mathbf{R P}$ & $\mathrm{RP}+20$ & $\mathbf{R P}$ & $\mathbf{R P}+20$ & $\mathbf{R P}$ & $\mathrm{RP}+20$ & $\mathbf{R P}$ \\
\hline 7.5 & 16.6 & 16.7 & 21.0 & 21.1 & 16.2 & 16.3 & 20.2 & 20.3 \\
\hline 8.0 & 16.6 & 16.7 & 21.0 & 21.1 & 16.2 & 16.3 & 20.2 & 20.3 \\
\hline 8.5 & 16.6 & 16.7 & 21.0 & 21.1 & 16.2 & 16.3 & 20.2 & 20.3 \\
\hline
\end{tabular}

Note: The description $R P+20$ refers to the $R P 2000+20$ table with reduced mortality in 20 years, and $R P$ refers to the $R P$ - 2000 . $E C$ n. 103 indicates a change in social security legislation in 2019.

Source: Prepared by the authors.

Before the reform, the rate using the RP-2000 biometric table is $16.2 \%$ in the entry pattern. There is a reduction of $0.1 \%$ due to the increased life expectancy, the same reduction observed in the stock base before the reform. Compared with EC n. 88, the reform through EC n. 103 increases the rate in the stock base in both mortality tables by $4.4 \%$. Considering the entry base, the increase was
$4 \%$ in both life expectancy scenarios. As this is the first study on the rates of unscheduled benefits for the RPC, the results could not be compared with the literature. However, the balance rates before the reform are close to the $17.95 \%$ rate adopted by Funpresp-Exe (Funpresp, 2013). Table 4 presents the specific balance rates for the different demographic, biometric, and legal scenarios.

Table 4

Specific balance rates $\bar{\tau}_{a}(\%)$ for costing the plan's unscheduled benefits, disaggregated by stock configuration and worker flow

\begin{tabular}{|c|c|c|c|c|c|c|c|c|}
\hline \multirow{3}{*}{ Costing $\left(\bar{\tau}_{\boldsymbol{\imath}}\right)$} & \multicolumn{4}{|c|}{ Stock } & \multicolumn{4}{|c|}{ Entry flow } \\
\hline & \multicolumn{2}{|c|}{ EC n. 88} & \multicolumn{2}{|c|}{ EC n. 103} & \multicolumn{2}{|c|}{ EC n. 88} & \multicolumn{2}{|c|}{ EC n. 103} \\
\hline & $R P+20$ & $\mathbf{R P}$ & $R P+20$ & $\mathbf{R P}$ & $R P+20$ & $\mathbf{R P}$ & $R P+20$ & $\mathbf{R P}$ \\
\hline AL_AT $\left(\tau_{1}\right)$ & 0.5 & 0.6 & 1.1 & 1.4 & 0.3 & 0.3 & 0.8 & 1.0 \\
\hline $\mathrm{AL} \_\mathrm{Al}\left(\tau_{2}\right)$ & 8.1 & 8.0 & 11.4 & 11.3 & 7.4 & 7.4 & 10.6 & 10.5 \\
\hline AL_AIBSA $\left(\tau_{3}\right)$ & 0.7 & 0.7 & 0.9 & 0.9 & 0.7 & 0.7 & 0.9 & 0.8 \\
\hline $\mathrm{AL} \_\mathrm{AN}\left(\tau_{4}\right)$ & 4.6 & 4.6 & 4.7 & 4.6 & 5.1 & 5.1 & 5.1 & 5.1 \\
\hline AL_ANBSA $\left(\tau_{5}\right)$ & 2.7 & 2.8 & 2.9 & 2.9 & 2.7 & 2.8 & 2.8 & 2.9 \\
\hline Total & 16.6 & 16.7 & 21.0 & 21.1 & 16.2 & 16.3 & 20.2 & 20.3 \\
\hline
\end{tabular}

Note: The description $R P+20$ refers to the $R P 2000+20$ table with reduced mortality in 20 years, and $R P$ refers to the $R P-2000$. EC n. 103 indicates a change in social security legislation in 2019.

Source: Prepared by the authors.

The model indicates that the change impact in legislation was mainly concentrated in the AL_AT (pension for active participant's death) and AL_AI (disability retirement) rates. Respectively, there was an increase of close to $0.5 \%$ and more than $3 \%$. The increases occurred both on the stock base and entry flow base. As in the general analysis, the increase in life expectancy reduces the specific rates of AL_AT and AL_ANBSA. On the other hand, AL_AI showed an increase of $0.1 \%$ when the participants' longevity increased.

The analysis classified by the specific rates allows us to observe that the flow base requires a collective effort of $0.5 \%$ more than the stock base in AL_AN. This result is explained by the higher percentage of actuarial profiles entitled to the Extraordinary Contribution (AE) benefit. In contrast, the values for AL_AI and AL_AT were higher in the stock base, explained by the higher average age of the participants. Thus, despite the similarity between the general balance rates of the two workforce compositions, the proposed methodology allows to identify that the specific balance rates have a heterogeneous behavior.

\subsection{Proposal for Reform}

Given the impacts of the change in legislation resulting from EC n. 103 in AL_AT and AL_AI rates, an amendment to the Funpresp-Exe plan regulation is proposed for 
the pension benefits for the active participant's death and disability retirement depending on the length of

contribution time. The BP benefit initially expressed in Equation 8 is suggested to be calculated by:

$$
B P_{\text {proposal }}=\max \left\{\left[\operatorname{Average}\left(B C_{80 \%}\right)-R P P S\right] \cdot[T X] \cdot \frac{\% M C}{8.5 \%} \cdot 70 \% ; 2 \cdot U R P\right\}
$$

TX is a percentage that depends on the contribution time to Funpresp-Exe, determined by a minimum percentage $(L B)$ that increases the rate $\delta$ each year of contribution from a contribution time $t$. It is important to note that this rule is inspired by the change caused by EC n. 103 .

By simulating and combining the values of $\mathrm{t}=(5,10,15,20), \mathrm{LB}=(50 \%, 60 \%, 70 \%)$, and $\delta=(1 \%, 2 \%$ e $5 \%$ ), to keep the AL_AT rate close to $0.3 \%$, as seen in Table 4, considering the configuration of the entry flow before the reform, the manager can choose $\mathrm{LB}=60 \%, \mathrm{t}=$ $5, \delta=2 \%$ or $\mathrm{LB}=70 \%, \mathrm{t}=5, \delta=1 \%$. In this configuration, the benefit of BP starts with the proportion TX $=60 \%$ of the original value, presented in Equation 8 , and increases by $\delta=2 \%$ every year after $t=5$ years of contribution to Funpresp-Exe.

Similarly, Equation 11 presents the calculation proposal for the disability retirement benefit (BAI), which depends on the time of contribution to the plan.

$$
B A I_{\text {proposal }}=\max \left\{\left[\operatorname{Average}\left(B C_{80 \%}\right)-R P P S\right] \cdot[T X] \cdot \frac{\% M C}{8.5 \%} ; 2 \cdot U R P\right\}
$$

For this proposal, performing the same simulation for the combinations $\mathrm{t}=(5,10,15,20), \mathrm{LB}=(50 \%, 60 \%, 70 \%)$, and $\delta=(1 \%, 2 \%$ e $5 \%)$, to keep the AL_AI rate close to $7.4 \%$, as shown in Table 4 , the manager can choose
$\mathrm{LB}=60 \%, \mathrm{t}=5, \delta=2 \%$ or $\mathrm{LB}=70 \%, \mathrm{t}=5, \delta=1 \%$. It is interesting to note that the suggestion for the two rates, AL_AT e AL_AI, is the same, which would simplify the proposal to amend the regulation.

\section{FINAL CONSIDERATIONS}

This work proposes a methodology for calculating costing rates for unscheduled retirement and disability benefits with $\mathrm{DB}$ and VC characteristics in pension plans with scheduled benefits with Defined Contribution (DC) characteristics. The methodology is based on the calculation of actuarially fair rates, specific balance rates, and general balance rates for such benefits.

Through the proposed methodology, the impact of legal, demographic, and actuarial changes on the costing of unscheduled benefits in the supplementary pension plan of the executive's federal civil workers (Funpresp-Exe) was evaluated, classifying according to actuarial profiles and cost source. The changes in legislation resulting from EC n. 103 caused an increase of $4 \%$ in the general balance rate for the unscheduled benefits of Funpresp-Exe, causing the required rate to be higher than the rate adopted (17.95\%), indicating a risk to the actuarial balance.

The rates responsible for funding disability retirement (AL_AI) and the pension for the active participant's death (AL_AT) are sensitive to the date of entry into the pension plan and changes in the official pension plan legislation. Due to the increase in the percentage of civil workers with actuarial profiles with social security incentives, the impact of demographic change in the general rate is camouflaged by the different behavior between the $\mathrm{AL} \_\mathrm{AI}$ and $\mathrm{AL} \_\mathrm{AN}$ (normal retirement pension) rates. It demonstrates the benefits of calculation of specific balance rates, as proposed by this work. Also, the proposed methodology made it possible to suggest changes to the regulations that control actuarial risks and prevent the increase in the rate.

The use of different family arrangements, changes in interest rates, and other decreases, such as leaving the RPC and entering the workers through the migration from the RPPS to the RPC, are limitations of the work and suggest paths for further research. Evidence of heterogeneity in real growth in civil workers' salaries also suggests the need to expand the number of actuarial profiles, considering more careers.

While applied to Funpresp-Exe, the proposed methodology can, without loss of generality, be adapted for any pension plan, mainly because it was modeled on a pension plan that offers benefits with $\mathrm{DC}, \mathrm{DB}$, and VC characteristics, which conventionally are not analyzed by the literature. 


\section{REFERENCES}

Actuaries Society. (2000). The RP-2000 mortality tables. Retrieved from https://www.soa.org/.

Afonso, L., \& Lima, D. (2011). Uma análise dos aspectos distributivos da aposentadoria por tempo de contribuição do INSS com o emprego de matemática atuarial. Revista Gestão \& Políticas Públicas, 1(2), 7-33.

Alonso-García, J., Boado-Penas, M., C., \& Devolder, P. (2018). Adequacy, fairness and sustainability of Pay-As-You-GoPension-Systems: Defined benefit versus defined contribution. The European Journal of Finance, 24(13), 1100-1122.

Ayuso, M., Bravo, J. M., \& Holzmann, R. (2016). Addressing longevity heterogeneity in pension scheme design and reform. IZA Discussion Paper, (10378).

Belloni, M., \& Maccheroni, C. (2013). Actuarial fairness when longevity increases: an evaluation of the Italian pension system. The Geneva Papers on Risk and Insurance - Issues and Practice, 38(4), 638-674.

Cardoso, S. C. P. (2013). Demonstração atuarial LEGISPREV. (Technical Report). Brasília, DF: Funpresp.

Castro, M. C. (1997). Entradas e saídas no sistema previdenciário brasileiro: uma aplicação de tábuas de mortalidade. (Doctoral Thesis). Universidade Federal de Minas Gerais. Belo Horizonte.

Conselho de Gestão da Previdência Complementar. (2005) Resolução MPS/CGPC no 16, de 22 de novembro de 2005. Retrieved from http://www.previc.gov.br/regulacao/normas/ resolucoes/resolucoes-cgpc

Corrêa, C. S. (2018). Premissas atuariais em planos previdenciários: uma visão atuarial-demográfica. Curitiba: Appris.

Dickson, D. C., Hardy, M., Hardy, M. R., \& Waters, H. R. (2013). Actuarial mathematics for life contingent risks. New York, NY: Cambridge University Press.

Donnelly, C. (2015). Actuarial fairness and solidarity in pooled annuity funds. ASTIN Bulletin, 45(1), 49-74.

Fernandes, R., \& Gremaud, A. P. (2003). Texto para discussão 1: Regime de previdência dos servidores públicos: equilíbrio financeiro e justiça atuarial. Brasília, DF: ESAF.

Freire, D. R., \& Afonso, L. E. (2015). Are the contribution rates of the Social Security General Regime (RGPS) sufficient? An actuarial study for retirement by length of contribution and survivors benefits. Revista Brasileira de Risco e Seguro, 11(19), $1-25$.

Fundação de Previdência Complementar do Servidor Público (Funpresp). (2013). Regulamento do plano de benefício da previdência complementar do poder executivo federal. (Regulamento). Retrieved from https://www.funpresp.com.br/ nossos-planos/execprev-participante-ativo-normal/.

Fundação de Previdência Complementar do Servidor Público (Funpresp). (2015). Relatório de fundamentação das premissas atuariais atualizadas na avaliação atuarial de 2014. (Technical Report). Retrieved from https://www.funpresp.com.br/ transparencia/transparencia/relatorio-anual/2014/.
Giambiagi, F., \& Afonso, L. E. (2009). Cálculo da alíquota de contribuição previdenciária atuarialmente equilibrada: uma aplicação ao caso brasileiro. Revista Brasileira de Economia, 63, 153-179.

Gouveia, A. L. L. A., Souza, F. C. d., \& Rêgo, L. C. (2018). Justiça atuarial nos cálculos previdenciários: aplicação de um modelo multidecremental para comparação da regra do fator previdenciário e da idade mínima. Revista Contabilidade \& Finanças, 29(78), 469-486.

Heiland, F., \& Yin, N. (2014). Have we finally achieved actuarial fairness of social security retirement benefits and will it last? Michigan Retirement Research Center. Working Paper, (2014307). Retrieved from http://hdl.handle.net/2027.42/109395.

Kolling, R., Petri, S. M., \& Marques, T. O. (2012). Análise dos planos de benefícios do Instituto de Seguridade Social dos Correios e Telégrafos: um estudo de dois casos no plano benefício definido Saldado e POSTALPREV. ConTexto, 12(22), 75-85.

Lei no 12.618, de 30 de abril de 2012. (2012, 2 de maio). Diário Oficial da União. Retrieved from http://www.planalto.gov.br/ ccivil_03/_ato2011-2014/2012/lei/112618.htm

Martins, F. G. L., \& Campani, C. H. (2019). Quem perde e quem ganha com a PEC 287/2016? Uma análise pela variação da riqueza atuarial do segurado urbano brasileiro do regime geral de previdência social. Revista de Administração Pública, 53(2), 432-460.

Meneu, R., Devesa, E., Devesa, M., Domínguez, I., \& Encinas, B. (2016). Adjustment mechanisms and intergenerational actuarial neutrality in pension reforms. International Social Security Review, 69(1), 87-107.

Ministério do Trabalho e Previdência Social (MTPS). (2016). Nota técnica MTPS 088/12 (Technical Report). Retrieved from $\mathrm{ftp}: / / \mathrm{ftp} . \mathrm{mtps}$.gov.br/pdet/microdados.

Oliveira, F. E. B., Beltrão, K. I., \& Maniero, L. V. F. (1997). Alíquotas equânimes para um sistema de seguridade social. Instituto de Pesquisa Econômica Aplicada. Texto para Discussão, (0524).

Pinheiro, R. P. (2005). Riscos demográficos e atuariais nos planos de benefício definido e de contribuição definida num fundo de pensão. (Doctoral Thesis). Universidade Federal de Minas Gerais, Belo Horizonte. Retrieved from http://hdl.handle. net/1843/MCCR-6W9PQK.

Queisser, M., \& Whitehouse, E. (2006). Neutral or Fair?: Actuarial concepts and pension-system design. OEDC Social, Employment and Migration Working Papers, (40). Retrieved from https://www.oecd-ilibrary.org/social-issues-migrationhealth/neutral-or-fair_351382456457.

Rangel, L. A., \& Saboia, J. L. (2013). Criação da previdência complementar dos servidores federais: motivações e implicações na taxa de reposição das futuras aposentadorias. Instituto de Pesquisa Econômica Aplicada. Texto para Discussão, (1847). Retrieved from https://www.ipea.gov.br/ portal/images/stories/PDFs/TDs/td_1847.pdf. 
Ribeiro, A. J. F. (2006). Um estudo sobre mortalidade dos aposentados por invalidez do regime geral da previdência social (RGPS). (Doctoral Thesis). Centro de Desenvolvimento e Planejamento Regional, Universidade Federal de Minas Gerais, Belo Horizonte. Retrieved from http://hdl.handle. net/1843/MCCR-6VSQ5D.

Rodrigues, D. D., \& Afonso, L. E. (2015). O impacto da criação da Funpresp sobre os benefícios previdenciários dos servidores públicos federais. Revista de Administração Pública, 49(6), 1479-1505.

Santos, C. H. M., Martins, F. S., Cavalcante, C. V., \& Mattos, L. M. (2018). O quão compatíveis são os dados da RAIS e os dos demonstrativos previdenciários brasileiros: estimativas preliminares para o período 2006-2015. In Ministério da Fazenda. Regimes previdenciários e situação atuarial. Brasília, DF: MF.

Souza, F. C. (2018). A heterogeneidade da mortalidade da população brasileira e aspectos distributivos na previdência social: uma análise atuarial da proposta de idade mínima de aposentadoria. Administração Pública e Gestão Social, 10(1), 2-11. Retrieved from https://periodicos.ufv.br/apgs/article/ view/5439/html

Yang, S. S., \& Huang, H. C. (2009). The impact of longevity risk on the optimal contribution rate and asset allocation for defined contribution pension plans. The Geneva Papers on Risk and Insurance - Issues and Practice, 34(4), 660-681.

\section{APPENDIX A}

\section{Notation for the actuarial NET:}

$\operatorname{NBP}\left(\tau_{1}\right)$ is the actuarial NET for BP and BPS benefits, considering a $\tau_{1}$ rate for $\mathrm{AL} \_\mathrm{AT} ; \operatorname{NBAI}\left(\tau_{2}\right)$ is the actuarial NET for the BAI, BAIP, and BAIPS benefits, considering a $\tau_{2}$ rate for AL_AI; NBAIS $\left(\tau_{3}\right)$; is the actuarial NET for the BAIS, BAISP, and BAISPS benefits, considering a $\tau_{3}$ rate for AL_AIBSA; $N B A N P\left(\tau_{4}\right)$ is the actuarial NET for the BAN, BANP, and BANPS benefits, considering a $\tau_{4}$ rate for AL_AN; $\operatorname{NBANPS}\left(\tau_{5}\right)$; is the actuarial NET for the BANS, BANSP, and BANSPS benefits, considering a $\tau_{5}$ rate for $A L \_A N B S A$.

\section{Notation for ages or time points:}

I is the entry age into the RPC; II is the retirement age; III is the expected age of the normal retirement benefit; IV is the expected age for the payment of the disability retirement benefit; $\mathrm{V}$ is the expected age for the payment of the pension benefit; VI is the expected age for the payment of the pension benefit for the death of the participant retired due to disability; VII is the expected age of the death benefit of the participant in normal retirement; VIII is the expected age of the participant's pension benefit for normal retirement survival benefit; IX is the age expected for the payment of the participant's death pension benefit for disability retirement survival benefit.

\section{Notation for time points of death, disability, death of the disabled, and death of the retired participant:}

$k$ is the index for the age at death of the participant; $x$ is the index for the age at disability; $y$ is the index for the age at death of the disabled participant; $z$ is the index for the age at death of the retired participant.

\section{Notation for representing the probabilities of death and survival:}

$q_{1, k}{ }^{(m o r)}$ is the probability of death in multiple decreases of the participant in $k ; p_{1}{ }^{(m o r, i n v)}$ is the probability of survival in multiple decreases of the participant; $p_{1}^{\left({ }^{(m o r)}\right.}$ is the participant's probability of survival to death (unidecremental); $q_{1, x}{ }^{(i n v)}$ is the probability of disability in multiple decreases in $x$; ${ }^{\text {inv }} p_{2}{ }^{(m o r)}$ is the disabled's probability of survival (unidecremental); ${ }^{i n v} q_{2, y}{ }^{(m o r)}$ is the probability of death of the disabled participant in $y$ (unidecremental); $p_{3}{ }^{(m o r)}$ is the probability of survival of at least one pensioner. 
Notation for representing the present value of contributions (VPC) and benefits (VPB):

$R(\tau, q, t)$ is the present value of the sum of the remaining value of the individual reserve (RI minus the amount paid for normal retirement if the participant dies after II) and accumulated contribution to the rate $\tau$ until time $t$, considering $q$ the survival probability; $B P$ is the present value of the death benefit of the active participant paid after $k$ and while the pensioner is alive/eligible or up to $V$; $B P S$ is the present value of the pension survival benefit for death of the active participant paid after $\mathrm{V}$ and while the pensioner is alive/eligible; BAI is the present value received from a disability retirement benefit paid after $x$ and up to $y$; BAIP is the present value of the disability pension benefit paid after $y$ and while the pensioner is alive/eligible or up to VI; BAIPS is the present value of the disability retirement survival benefit paid after VI and while the pensioner is alive/eligible; BAIS is the present value for the disability retirement survival benefit paid after $V$ and while the participant is alive; BAISP is the present value of the disability retirement pension benefit paid while the pensioner is alive/eligible or up to IX; BAISPS is the present value of the disability retirement survival pension benefit paid after IX and while the pensioner is alive/ eligible; $B A N P$ is the present value of the pension benefit for the death of the participant in normal retirement and occasional Extraordinary Contribution (AE) paid after $z$ and while the pensioner is alive/eligible or up to VII; BANPS is the present value of the pension survival benefit for the death of the participant in normal retirement and occasional AE paid after VII and while the pensioner is alive/eligible; BANS is the present value of the retiree's survival benefit and occasional AE paid after III and while the participant is alive; BANSP is the present value of the pension survival benefit due to the death of the survival participant and occasional AE paid after $z$ and while the pensioner is alive/eligible or up to VIII; BANSPS is the present value of the survival benefit of the pension survival benefit and occasional AE paid after VIII and while the pensioner is alive/eligible.

\section{Notation for actuarial NET equations}

$$
\begin{gathered}
N B P\left(\tau_{1}\right)=\sum_{k=I}^{I I} q_{1, k}^{(m o r)}\left(R\left(\tau_{1}, p_{1}^{(m o r, i n v)}, k\right)-B P\left(p_{3}^{(m o r)}, I, k, V\right)-B P S\left(p_{3}^{(m o r)}, I, k, V\right)\right) \\
N B A I\left(\tau_{2}\right)=\sum_{x=I}^{I I} q_{1, x}^{(i n v)}\left(R\left(\tau_{2}, p_{1}^{(m o r, i n v)}, x\right)-\left(\sum _ { y = x } ^ { I V } { } ^ { i n v } q _ { 2 , x , y } ^ { ( m o r ) } \left[B A I\left({ }^{i n v} p_{2}^{(m o r)}, I, x, y\right)+\right.\right.\right. \\
\left.\left.\left.B A I P\left(p_{3}^{(m o r)}, I, x, y, V I\right)+B A I P S\left(p_{3}^{(m o r)}, I, x, y, V I\right)\right]\right)\right) \\
N B A I S\left(\tau_{3}\right)=\sum_{x=I}^{I I} q_{1, x}^{(i n v)}\left(R\left(\tau_{3}, p_{1}^{(m o r, i n v)}, x\right)-\left(\sum _ { y = x } ^ { 1 2 0 } { } ^ { i n v } q _ { 2 , x , y } ^ { ( m o r ) } \left[B A I S\left({ }^{\text {inv }} p_{2}^{(m o r)}, I, x, y\right)+\right.\right.\right. \\
\left.\left.\left.B A I S P\left(p_{3}^{(m o r)}, I, x, y, I X\right)+B A I S P S\left(p_{3}^{(m o r)}, I, x, y, I X\right)\right]\right)\right) \\
N B A N P\left(\tau_{4}\right)=\sum_{z=I}^{I I I} q_{1, z}^{(m o r)}\left(R\left(\tau_{4}, p_{1}^{(m o r)}, z\right)-B A N P\left(p_{3}^{(m o r)}, I, z, V I I\right)-B A N P S\left(p_{3}^{(m o r)}, I, z, V I I\right)\right) \\
N B A N S\left(\tau_{5}\right)=\sum_{z=I}^{120} q_{1, z}^{(m o r)}\left(R\left(\tau_{5}, p_{1}^{(m o r)}, z\right)-B A N S\left(p_{1}^{(m o r)}, I, z, V I I I\right)-\right. \\
\left.B A N P\left(p_{3}^{(m o r)}, I, z, V I I I\right)-B A N S P S\left(p_{3}^{(m o r)}, I, z, V I I I\right)\right)
\end{gathered}
$$

